\title{
Systemics, Excellence, Global Enterprising and Business Ethics ${ }^{1}$
}

\author{
By
}

\author{
John Thanopoulos ${ }^{2}$, George Chandrinos, Panos Petratos \\ and Nikitas Assimakopoulos
}

The corporate globalization produced a platform for interactive thinking and world-wide usage of concepts that up to recently were locally confined because of inability to communicate, tribal impositions and business avarice priorities of the wealthy and those in power. Based on similar to the previously stated thoughts, this article illustrates:

1. Why systemics, directives of excellence, global enterprising, focusing on human resources, sound corporate governance and business ethics are shaping a new era of societal betterment for all.

2. The belief that the propelling power of the new era is the individual worker. His/her thorough selection, according to the specific needs of each organization, is key for organizational growth and employee happiness.

3. The central role that philosophy, ethics and psychology play for all human activities.

4. The essence of human happiness and meaning of life, these being the major reasons for meaningful existentialism.

5. The dangers that appear to be ante portas, especially due to technological advancements, robotics, imitation, and status perceptions.

6. That thorough corporate governing codes apply to all organizations, irrespective of location, size, industry, public or private, and result in significant improvement of all social strata.

This work is based on "meta" research findings of the last fifty years, suggests areas to further specific topics of academic interest and it is analyzed in the following headings:

- Physical and Political Boundaries,

- The Global Corporation,

- Codes of Governance and Business Ethics,

- Implications from Information Technologies, the Media and Marketing,

- Setting New Standards of Human Coexistence: Meaning of Life,

- A "Systemic" World.

\footnotetext{
${ }^{1}$ This, as a position paper, was partially addressed at the $13^{\text {th }}$ Annual National and International Conference of HSSS in June 2017 at Sparta, Greece, capitalizing on the phenomenal changes that the systemic world experienced in the last half of this century. Among many others, the following examples pointed to the new trends: John Gall's, Systemantics: How Systems Work and Especially How They Fail, published by Quadrangle, The New York Times Book Co., 1975; Max Ways, Business Is Facing Growing Pressures to Behave Better, published by Fortune, May 1974, pages 192-195, 310, $314,316,319-320$. The present work includes information from the author's co-authored with Panos Petratos Business Ethics Theory, Amazon 2015 and the main author's textbook on Global Business and Corporate Governance, published by Business Expert Press, New York 2014.

${ }^{2}$ Contact author John Thanopoulos, Ph.D., Professor of International Business, and Dean, Business and Economics, IST; Emeritus Professor, University of Piraeus; World Education Congress's Best International Business Professor (2012). Telephone ++30210-4822222, fax: ++30210-4821850. Emails: jt@unipi.gr, jt@ist.edu.gr, thanioa@otenet.gr .
} 
In a cosmic horizon of billions of light years and trillions of planets, our tiny Earth is "sand in the wind!" 3 Yet, homo erectus appeared only very recently and in less than 50,000 years he has managed to leave his footprint in more than $80 \%$ of the land surface of our planet ${ }^{4}$.

Historically, and to a great extent, human daily functions were and are based on classical Freudian concepts ${ }^{5}$ and enterprising elements which can be seen from making a pair of ancient scandals to building a pyramid and from the Silk $\operatorname{Road}^{6}$ to the wars of Napoleon.

\section{PHYSICAL AND POLITICAL BOUNDARIES}

Homo Erectus, following the successful practice of other advanced animal life of the past, developed habitual behaviors in quasi-tribal realities. In a tribal environment it was easier to find shelter, food, security. Effectively during less than ten thousand years, one may observe that the past rulers, aimed towards self-serving objectives, moving tribal behaviors beyond primitive pathways and creating state organizations, behavioral protocols, production means, legal structures, defensive and occupational armies, political power, both inside and outside the countries they ruled.

They built tall walls to protect their perceived belongings and they capitalized on physical, social and linguistic characteristics. They understood that for the great majority of people, the meaning of life had always the element of belonging, often perceived as a family, a tribe, a country, an empire, an organization or a religion. Sequentially, and within these tall walls, specific habitual behaviors ${ }^{7}$ were developed usually cultivated through physical barriers, legal imposition, common languages, religious thinking and the forceful superior power of the rulers.

Now, the reader is asked to press the fast forward button. The well-known astrophysicist Stephen Hawking, as well as many others, feels that humanity needs to get off of Earth as soon as 100 years from now quoting issues from climate to the ever growing population ${ }^{8}$.

In fact, we are, world-wide, in front of major global pressures that demand our advanced philosophical perspectives not only with respect to the headings, The Global Corporation and Codes of Governance and Business Ethics, but also with respect to standards of operational excellence, self-actualization of

\footnotetext{
${ }^{3}$ Though the concept reminds a well-known song, to better understand the argument the reader is advised to study the 'observable universe' a conceptual region of our Universe and relate it to the 'cosmological expansion'. Scientists refer to trillion of galaxies existing in the observable universe. In this sense, in the observable universe, there are more stars than all the grains of sand of our planet.
}

${ }^{4}$ Hillary Mayell, Human "Footprint" Seen on 83 Percent of Earth's Land, National Geographic News, October 25, 2002.

${ }^{5}$ For example, see Saul McLeod, Id, Ego and Superego, at Simply Psychology, published in 2007 and updated in 2016.

${ }^{6}$ The Silk Road, named so by geographer Ferdinand von Richthofen, is a well-known international trade ancient road between China and the Mediterranean used in bringing worthy Far East products, such as the Chinese silk.

${ }^{7}$ Habitual behaviors are leading contemporary practices, like "The dotcom crash in 2000-02 caused losses to shareholders worth $\$ 4$ trillion and a mild recession. Leveraged global banks notched up losses of $\$ 2$ trillion in 2007-10 and the world economy imploded." The Economist, May $16^{\text {th }} 2015$, 'The great distortion', page 9.

${ }^{8}$ Mike Wehner, Stephen Hawking wants humanity to leave Earth as soon as possible, BGR, (Boy Genius Report), June 22, 2017. 
the human and true meaning of life that should have not only the element of belonging, but also of purpose, of existence reasoning and of transcendence.

The after World War II years brought a shift in political power, and significant reduction of economic and social barriers. These new elements brought the era of global business, new demands from the previously depressed populations, a better understanding of education needs and a more unified ethical reality. Moreover, they brought a shift of the meaning of 'democracy' by effectively replacing it with the meaning of 'meritocracy" , therefore, to a great extent provoking the decline of previously well accepted political positions and the existing culture on cross-national differences in company reputations (and until then well-rooted government organizations) ${ }^{10}$. At the same time, and given advances in Information Technologies (IT), new venues of criminal activity ${ }^{11}$ and strong debates about the worthiness and significance of equality legal ${ }^{12}$ roles appear.

\section{THE GLOBAL CORPORATION}

Though the impact of 'foreignness' carried and will continue to carry disputable means of cultural understanding ${ }^{13}$, in our opinion the essence of the $21^{\text {st }}$ century Global Corporation can be summarized in two words: Philosophical change! We believe that in the era of Global Corporation the overriding factor is a focal change from the stockowners and their financial benefit to the stockholders and the benefit in terms of social improvement. Simply, we are the observers of a thousand years old habit: The enterprising profit instead of going to the wealthy and the people of power goes for the societal betterment ${ }^{14}$. To some extend we should also examine underlying causes of the backlash against globalization ${ }^{15}$. Do they apply equally to different parts of the world?

${ }^{9}$ The reader is advised to see the opposite side of this argument, too! It is stated that: "The enduring power of families in business and politics should trouble believers in meritocracy," this being the opening statement of the main article of The Economist, April 18 2015 , under the name 'Dynasties', page 7.

10 Deephouse, D. L., Newburry, W., \& Soleimani, A., The effects of institutional development and national culture on cross-national differences in corporate reputation. Journal of World Business, 2016, 51(3), pages 463-473.

${ }^{11}$ For example, in 2016 hackers drained a total of around $\$ 3.2$ million from more than 9,000 accounts in TESCO Bank and were selling name and password information for more than 117 million accounts of Linkedin. Jeff John Roberts and Adam Lashinsky. Hached, Fortune, July 1, 2017, pages 25-31.

${ }^{12}$ Catherine Barnard and Alysia Blackham, Self-Employment in EU Member States: The Role for Equality Law, European equality law review, 2/2015, pages 1-13. Note that even the title of this journal connotes the potential of a dispute of the role of legal equality.

${ }^{13}$ Markus Taussig, Foreignness as both global asset and local liability: How host country idiosyncrasies and business activities matter, Journal of International Business Studies, 2017, 48, pages $498-522$.

${ }^{14}$ In textbook terms, in English, see John Thanopoulos, Global Business and Corporate Governance: Environment, Structure and Challenges, New York, Business Expert Press 2014, and Global Business: Environment, Structure and Challenges, Athens, Greece, Interbooks 2007. Some of the relevant articles on teaching this field include "Teaching International Business in 'Mega' Classes: Active learning and Team-building," (with Nikos Papazoglou), manuscript reference number JHETP35616, Journal of Higher Education Theory and Practice, 2017; "How to Add Philosophy Dimensions in Your Basic International Business Course," Journal of Teaching in International Business, Volume 21 (Issue 3), July-September 2010, pages 189-199; "Teaching International Business in 'Mega' Classes: A Case Study," Journal of Teaching in International Business, Volume 15 (Number 3), 2004, pages 61-76; "Towards Global Entrepreneurialism," (with L. L. Schkade), North Central Business Journal, Volume I, Issue 7, Summer/Fall 2000, pages 46-7; "The Brave New Global 
Due to IT and media expansion today's business, enterprising of any size, industry or nationality, has a world-wide reach. An Argentinian restaurant may use a Belgian recipe, a Canadian factory capitalizes on a Danish patent, an English travel agency sends its customers to vacation in France, and so on. Already, in most instances, there are physical, legal or political barriers and if present trends continue in about thirty years our social world should not experience any of them.

We should also consider the trends towards the size and the overall quality of modern business. Examples:

- The total revenues of the 500 largest global corporations exceed $\$ 27,634$ billion, their profits $\$ 1,481$ billion, their assets $\$ 118,281$ billion and they employ only 67 million employees ${ }^{16}$, less than the $1 / 100$ of the world's population.

- In comparison, the IMF indicated Gross Domestic Product (GNP) in nominal values is about $\$ 78$ trillion, which can be translated that the total revenues of the 500 largest global corporations exceed the one-third of the global GNP.

- To put it in a different way, the $500^{\text {th }}$ of those companies has largest revenues than the GNP of countries like Cyprus, Bosnia and Herzegovina, Botswana, Jamaica, Senegal, Zimbabwe and so on.

- The interested reader is advised to study also the lists of (a) Most Admired Companies and (b) Fastest Growing Companies of the World, both annually published by Fortune.

In our opinion, most of the 500 largest global corporations, and millions of others, are cognizant of the fact that beyond their traditional functions, like accounting, finance, management or marketing, they are witnessing and have to adapt to the previously mentioned philosophical change!

\section{CODES OF GOVERNANCE AND BUSINESS ETHICS}

Corporate philosophy change is the major propelling force of the $21^{\text {st }}$ Century successful enterprising. The backbone of this change is the existence of codes of corporate governance, the equivalent of a country constitution. As with a country constitution, a code of corporate governance indicates the philosophical predisposition of its stakeholders and it may change every time that a major shift happens either at the ownership level or at the corporate investment orientation ${ }^{17}$. From such a statement, which should be concise, straightforward and simple to understand, the corporate operation manuals should outline specific functions, objectives and processes.

Enterprise," (with Charles Little), Review of Business, Volume 20 (Number 2) Winter 1998, page 3; "Global Business Education for the 21 $1^{\text {st }}$ Century," Review of Business, Volume 20 (Number 2) Winter 1998, pages 31-33. "International Business Education in the AACSB Schools," (with Ivan R. Vernon), Journal of International Business Studies, Volume 18, Number 1, 1987, pages 91-98.

${ }^{15}$ Contractor, Farok J., Global Leadership in an Era of Growing Nationalism, Protectionism, and AntiGlobalization, Rutgers Business Review, 2017 Volume 2, Number 2, pages 163-185.

${ }^{16}$ Fortune, August 1, 2016, page F-10.

17 The specificities of the country (ies) involved, company infrastructure and the investors profiles also a major roles. Anish Sugathan and Rejie George, The influence of governance infrastructure and corporate governance on profit sharing, Journal of International Business Studies, 2015, 46, pages 886-916; Ruth V. Aquilera, Kurt A. Desender, Monica Lopez-Puertas Lamy and Jun Ho Lee, The governance impact of a changing investors landscape, Journal of International Business Studies, 2017, 48, pages 195-221. 
In a simplified depiction, most of the organization and business leaders that aspire to manage during this new era, follow the Caux Round Table (CRT) principles of moral capitalism ${ }^{18}$. In a summary format these principles define: Respect of stakeholders beyond the shareholder benefits; Contribution towards the economic, social and overall environmental betterment; building trust beyond what the law requires; respect the local cultures, rules and industry conventions; support in a responsible manner the globalization potential of each business undertaking; respect the environment; avoid illicit activities. They also clearly pronounce the corporate responsibility towards its customers, its employees, its shareholders, its suppliers, its competitors, as well as the communities they serve.

Furthering the CRT concept, in a classic sense, these principles are based on meaning of the Japanese word kyosei ${ }^{19}$ and at the desire to further promote human dignity. In simple terms the after World War II global social pressures necessitated a managerial shift towards what Max Ways states as "business faces growing pressures to behave better ${ }^{20}$."

Welcome dear reader to the business ethics era, admittedly practiced in different ways around the globe, but certainly respected by a great number of organizations and business concerns, taught in hundreds of universities and constantly updated in thousands of articles and texts. Nevertheless, also focus into examining how different governance codes of international $R \& D$ capitalize on captive offshoring and outsourcing, indirectly contributing to innovation and corporate growth ${ }^{21}$. Is this ethical behavior?

\section{IMPLICATIONS FROM INFORMATION TECHNOLOGIES, THE MEDIA AND MARKETING}

While addressing matters of information, media, marketing or technology, a common term of previously referred as 'habitual behaviors' 22 often appears. Habits are the propelling factors for most behaviors and evolution of the animal life. However, for the purpose of this work we need to concentrate on the above elements of the global corporation and the respective human undertakings of the last fifty years.

All of these are of major impact for the $21^{\text {st }}$ century enterprise. For example, IT is not only a computer application to store, study, retrieve, transmit, or manipulate data or information. It also manifests valid but sometimes questionable methodologies in data handling, often counterproductive for the corporate well-being. Users of this information should often question its validity and potential. Moreover, 'deep learning' and artificial intelligence (AI) expansion may result in neutralizing the human spiritual development and even lead in true human slavery. Some researchers propose to humanize IT and well-

\footnotetext{
18 The CRT Principles for Business were the outcome of a series of discussions between executives from Europe, Japan, and the United States at the Caux Round Table during the late 1980's and early 1990's and eventually produced a document called "The Minnesota Principles." They have been published in several languages and broadly appear in textbooks, articles, and addressed in business school curricula worldwide. See also the Cadbury Code (1992),
}

${ }^{19}$ The concept "kyosei" means living and working together for the common good, thus enabling cooperation and mutual prosperity in an environment that promotes coexistence with healthy and fair competition.

\footnotetext{
${ }^{20}$ Max Ways, Business Faces Growing Pressures to Behave Better, Fortune, May 1974, page 193.

${ }^{21}$ Alicia Rodríguez and María Jesús Nieto, Taking Advantage of R\&D Offshoring beyond Innovation, Rutgers Business Review, 2017, Volume 2, Number 2, pages 251-257.
}

${ }^{22}$ See section on Physical and Political Boundaries. 
known figures in this field, like Elon Musk, fear that "the development of AI may be the biggest existentialist threat that humanity faces ${ }^{23}$ ".

Mass media, TV, radio, newspapers, magazines, but also IT-related means, play today a similar role ${ }^{24}$ often due to the fact that immediacy is required in reporting. In itself this reduces the audience's ability to compare and to contrast and to study opposing perspectives and/or to do in-depth research. The very existence of mass media relates to income from advertising and to the desires of people of power. Also consider that media organizations usually target themselves on what is easier and most desirable to be accepted from the population masse ${ }^{25}$. Eloquent thinking with philosophical repercussions is not the norm. Think also that company promotions, a major marketing element, primarily materializes though mass media.

Speaking of marketing one should examine the extent the best global universities are for the last decades preparing the new generations of marketing executives. The business focus of even today's marketing graduates is still the consumer and how he/she will enhance the corporate wealth through manipulation of the product-service continuum, target marketing, need creation, positioning, and ability to affect the marketing mix (the 4Ps of marketing: offer right product, place, price, promotion). In our opinion during the new era of global enterprise the managerial focus has already started shifting towards true satisfaction of consumer needs, better utilization of the scarce resources of our planet and overall social improvement. The existing marketing means should be sufficient. Only a philosophical reorientation of business doings is needed.

So, as an implication from this section on information technologies, the media and marketing we wish to state that the global $21^{\text {st }}$ century enterprise should aim humanize IT and AI, expand the potential of freedom of thinking, offer marketing venues that reduce unnecessary customer choices and further promote the philosophical base of the individual. At the same time one should be very careful at the innovation potential ${ }^{26}$ of recently surfacing ventures that phenomenally expand and may project disputable options that gravely affect the harmonically balanced reality of the era of our globalized "village".

\section{SETTING NEW STANDARDS OF HUMAN COEXISTENCE: MEANING OF LIFE}

A few years ago a major business publication had an article entitle 'Set Your Employees Free ${ }^{27}$, quoting issues like 'freedom and responsibility culture' or 'focus on what people get done, not on how many days they worked. ${ }^{28}$, In March 2017 Fortune had on its cover 'How to Tap Into Your Inner Genius. $^{29}$,

${ }^{23}$ The dawn of artificial intelligence, The Economist, May $9^{\text {th }}$ 2015, page 9.

${ }^{24}$ As stated previously: ... in neutralizing the human spiritual development and even lead in true human slavery ...

${ }^{25}$ Observe also that even well-established major media vehicles Ine Bloomberg Businessweek, may devote whole issues on debatable matters, like 'Smart global journalism + Smart new design,' June 12-18. 2017.

${ }^{26}$ See the Global Tech Issue of Bloomberg Businessweek, July 3, 2017, pages 39-69.

${ }^{27}$ (As reported by Brad Stone) Reed Hastings, Set Your Employees Free, Bloomberg Businessweek, April 10-22. 2012, page 62.

${ }^{28}$ As quoted by Reed Hastings, the co-founder and CEO of Netflix.

${ }^{29}$ March $15^{\text {th }} 2017$, annual edition on 100 BEST COMPANIES TO WORK FOR: Everything you need to know to land your dream job. 
The question therefore arises: With respect to a hundred years ago, are we in front of a major shift of the human resource management (HRM) orientation and teaching? Indicative of HRM trends are statements like those ${ }^{30}$ :

- The most valuable people today are increasingly "relationship workers"

- By far the most important factor when professionals consider a new employer is whether it's a great place to work

- Perks don't make a great workplace. The real key is interpersonal relationships. Employees are more engaged where relationships thrive, in the smallest companies

- Millennials, who now dominate the workforce, are the hardest generation for employers to hold (this is particularly important for our 'resolution' at the next section

- A company's culture is even more important than its leadership.

The above should redefine global business, marketing and HRM AACSB teaching methodologies, especially at AACSB academic institutions ${ }^{31}$. Moreover, it implies the pragmatism of a new era where the amount of workforce remuneration is not the critical factor of employment. Instead companies should focus on variables like quality of relationships, work environment, workplace culture, recruiting, life-long education, self-actualization of the employee and so on.

In effect we are returning to the initial concern of meaning of life. In a past era of human slavery, from building a pyramid to whipping underperformers and from being life-long confined in a factory or in a merchant ship, where submission of the individual was a necessary condition, his or hers meaning of life were of trivial importance to the employment owners. Instead, and during the last fifty years, business ethics have become the central philosophical concern of many organizations aiming to enhance the employees meaning of life (belonging, purpose, storytelling and transcendence) as well as their self-actualization potential. This will enhance the coexistence among all animal life, redirect all efforts towards social betterment, avoid unnecessary resource spending and improve survival chances of the human race.

It is this self-actualization potential, greatly illustrated through Abraham Maslows' hierarchy of needs $^{32}$, that requires us to explore higher order human values, like responsibility for the inner life experiences, commitment to a cause greater than self, full use of one's powers along the lines of integrity, social betterment, excellence and caring ${ }^{33}$.

\section{A "SYSTEMIC" WORLD}

Concluding this work we believe that the essence of a systemic approach is a sine qua non proposition for the societal betterment for the years to come. Human focus should embrace self-actualization together with previously quoted higher order values like responsibility for the inner life experiences, commitment to a cause greater than self, full use of one's powers along the lines of integrity, excellence and caring.

We need to understand that more than seven billion humans need to coexist in a systemic new reality that by-passes the previously implied problems and aim towards constant social betterment. Directives

${ }^{30}$ Geoff Colvin, Personal Bests, Fortune, March 15th 2015 , pages 32-36.

${ }^{31}$ AACSB stands for the Association to Advance Collegiate Schools of Business, an organization that educationally leads the best business schools since 1916 .

32 A. H. Maslow, The Further Reaches of Human Nature, New York, The Viking Press, 1971, page 339 and A.H. Maslow, Motivation and Personality, New York, Harper and Row, 1970, page 165.

${ }^{33}$ Mullins, Larry with L. A. Stamford, The MetaValues Breakthrough, Morgan-James, Garden City, New York 20019, pages 162-166, 
of excellence require focusing on human resources, IT, global enterprising, sound corporate governance and business ethics. We need also to understand that well-developed corporate governing codes apply to all organizations, irrespective of location, size, industry, public or private, and result in significant improvement of all social strata.

Sound planning should significantly eliminate dangers due to technological advancements, robotics, imitation, and status perceptions. Finally, the propelling power of the new era is the individual worker. Therefore, his/her thorough selection, according to the specific needs of each organization, is key for organizational growth and employee happiness. Any organization must understand that, in accordance to the local perceptions, must advance the essence of philosophy, ethics, psychology and meaningful existentialism for all its stakeholders.

Welcome to the $21^{\text {st }}$ Century systemic world having as central propelling force philosophy and the meaning of life of the individual, smiley and creative ${ }^{34}$.

\section{REFERENCES}

Aquilera, Ruth V., Kurt A. Desender, Monica Lopez-Puertas Lamy and Jun Ho Lee, The governance impact of a changing investors landscape, Journal of International Business Studies, 2017, 48, pages 195-221.

Barnard, Catherine and Alysia Blackham, Self-Employment in EU Member States: The Role for Equality Law, European equality law review, 2/2015, pages 1-13.

Bloomberg Businessweek, Global Tech Issue of, July 3, 2017, pages 39-69.

Colvin, Geoff, Personal Bests, Fortune, March $15^{\text {th }}$ 2015, pages 32-36.

Contractor, Farok J., Global Leadership in an Era of Growing Nationalism, Protectionism, and AntiGlobalization, Rutgers Business Review, 2017, Volume 2, Number 2, pages 163-185.

Deephouse, D. L., Newburry, W., \& Soleimani, A., The effects of institutional development and national culture on cross-national differences in corporate reputation, Journal of World Business, 51(3), 2016, pages 463-473.

(The) Economist, April 18 2015 , 'Dynasties', page 7.

(The) Economist, May $16^{\text {th }} 2015$, 'The great distortion', page 9.

Fortune, March $15^{\text {th }}$ 2017, annual edition on 100 BEST COMPANIES TO WORK FOR: Everything you need to know to land your dream job.

Gall's, John, Systemantics: How Systems Work and Especially How They Fail, Quadrangle, The New York Times Book Co., 1975.

Maslow, A. H., The Further Reaches of Human Nature, New York, The Viking Press, 1971, page 339.

Maslow, A.H., Motivation and Personality, New York, Harper and Row, 1970, page 165.

Mayell, Hillary, Human "Footprint" Seen on 83 Percent of Earth's Land, National Geographic News, October 25, 2002.

McLeod, Saul, Id, Ego and Superego, Simply Psychology, 2007 (updated in 2016).

Mullins, Larry with L. A. Stamford, The MetaValues Breakthrough, Morgan-James, Garden City, New York 20019, pages 162-166,

Roberts, Jeff John and Adam Lashinsky. Hached, Fortune, July 1, 2017, pages 25-31.

Rodríguez, Alicia and María Jesús Nieto, Taking Advantage of R\&D Offshoring beyond Innovation, Rutgers Business Review, 2017, Volume 2, Number 2, pages 251-257.

${ }^{34}$ See Appendix: Resolution for Our Children! 
Sugathan, Anish and Rejie George, The influence of governance infrastructure and corporate governance on profit sharing, Journal of International Business Studies, 2015, 46, pages 886-916. Stone, Brad and Reed Hastings, Set Your Employees Free, Bloomberg Businessweek, April 10-22. 2012, page 62 .

Taussig, Markus, Foreignness as both global asset and local liability: How host country idiosyncrasies and business activities matter, Journal of International Business Studies, 2017, 48, pages 498-522.

Thanopoulos, John and Nikos Papazoglou, Teaching International Business in 'Mega' Classes: Active learning and Team-building, Journal of Higher Education Theory and Practice, 2017, pages 110-122. Thanopoulos, John and Panos Petratos, Business Ethics Theory, Amazon, 2015.

Thanopoulos, John, Global Business and Corporate Governance, Business Expert Press, New York, 2014.

Thanopoulos, John, How to Add Philosophy Dimensions in Your Basic International Business Course," Journal of Teaching in International Business, Volume 21 (Issue 3), July-September 2010, pages 189-199.

Thanopoulos, John, Teaching International Business in 'Mega' Classes: A Case Study, Journal of Teaching in International Business, Volume 15, Number 3, 2004, pages 61-76.

Thanopoulos, John and L. L. Schkade, Towards Global Entrepreneurialism, North Central Business Journal, Volume I, Issue 7, Summer/Fall 2000, pages 46-7.

Thanopoulos, John and Charles Little, The Brave New Global Enterprise, Review of Business, Volume 20, Number 2, Winter 1998, page 3.

Thanopoulos, John and Ivan R., Vernon, Journal of International Business Studies, Volume 18, Number 1, 1987, pages 91-98.

Ways, Max, Business Is Facing Growing Pressures to Behave Better, Fortune, May 1974, pages 192195.

Wehner, Mike, Stephen Hawking wants humanity to leave Earth as soon as possible, BGR, June 22, 2017. 


\section{Appendix: Resolution for Our Children}

Therefore, dear children and dear future employees of our global corporations, welcome to our new era of existentialism, culturally balanced progress, systemic realities, cooperation and sensitivity for all human and non-human life of our planet. Welcome to the era of managerial self-actualization and corporate pragmatism that effectively enhances the life purpose of millions of all people of our planet, not only of the employees of global organizations. This is an epoch that requires from all in-depth understanding of respect, dignity and constant effort to improve not only our organization's culture but also our community. This is a philosophical change of what our grandfathers experienced. Allow us to summarize our instructions to you through the following statements. Try your best ... remember, attitude is everything!

- Cultivate positive thinking!

- Reach your full potential!

- Educate constantly yourself aiming to self-actualize!

- Appreciate!

- Think out of the box!

- Embrace worldwide opportunities

Incidentally, if you take the first letter of each phrase above, you will get the word Create! Then, there is a set of additional instructions:

- Sky is the limit! Try your best!

- Make a difference!

- Impress to your environment Ethical behaviors!

- Let's think global!

- Earn respect from everyone!

Again, if you take the first letter of each phrase above, you will get the word $\underline{\text { Smile! }}$

Have a smiley and creative life's trip. Good luck! 